\title{
KEMITRAAN MASYARAKAT UNTUK PENGEMBANGAN EKOWISATA TANAH LOT
}

\author{
I Putu Ananda Citra \\ Jurusan Pendidikan Geografi, FHIS Universitas Pendidikan Ganesha \\ e-mail: ananda.citra@undiksha.ac.id
}

\begin{abstract}
Abstrak
Penelitian ini dilaksanakan di Daya Tarik Wisata Tanah Lot dengan tujuan 1) Mengidentifikasi peran para pihak terlibat dalam pengelolaan potensi ekowisata Tanah Lot, 2) Menganalisis bentuk kemitraan dalam pengembangan ekowisata Tanah Lot. Metode yang digunakan adalah metode survei untuk menggali informasi yang bersifat kualitatif, serta didukung dengan metode observasi secara langsung di lapangan, dan wawancara mendalam (indepht interview). Sampel ditentukan dengan teknik purposive. Analisis data dilakukan dengan teknik analisis deskriptif kualitatif. Hasil penelitian menunjukkan 1) pihak yang terlibat adalah pemerintah daerah, pemerintah desa dinas, desa adat, pelaku usaha wisata, 2) Bentuk kemitraan masyarakat untuk pengembangan ekowisata Tanah Lot berdasarkan status kepemilikan lahan.
\end{abstract}

Kata Kunci: Kemitraan, Ekowisata, Tanah Lot

\begin{abstract}
This research was conducted at Tanah Lot Tourism Attraction with the aim of 1) To identify the role of stakeholders in the management of Tanah Lot ecotourism potential, 2) To analyze the partnership form in Tanah Lot ecotourism development. The method used is qualitative method, with keyword. Induction interview. Samples with purposive technique. Data analysis was done by qualitative descriptive analysis technique. The results showed 1) the parties involved were local government, village government, adat village, tourism business actors, 2) the form of community partnership for ecotourism development of Tanah Lot based on land ownership status.
\end{abstract}

Key Words : Partnership, Ecotourism, Tanah Lot 


\section{PENDAHULUAN}

Ekowisata

(ecotourism)

merupakan hal yang menciptakan dan memuaskan suatu keinginan akan alam, mengeksploitasi potensi wisata untuk konservasi dan pembangunan serta mencegah dampak negatifnya terhadap ekologi, kebudayaan dan keindahan (Western, 1995:3). Dengan ekowisata diharapkan dapat menjamin keberlangsungan hidup pariwisata tanpa harus mengorbankan lingkungan. Dari prinsip pembelajaran tentang alam dan manfaatnya terhadap masyarakat, maka Bali memiliki potensi besar dalam pengembangan ekowisata karena Bali termasuk Kabupaten Buleleng, khususnya daya tarik wisata Tanah Lot yang memiliki sejumlah sumber daya alam dan potensi sosial budaya berupa adat-istiadat masyarakat yang mampu menopang pembangunan pariwisata.

Hal yang paling mendasar dalam pengelolaan tersebut yaitu untuk memasarkan potensi yang dimiliki yaitu dengan melakukan kerjasama/ bermitra dengan pelaku wisata. Hal ini merupakan salah satu strategi dalam mengembangkan objek wisata. Kemitraan antara desa adat dengan pelaku usaha wisata merupakan salah satu strategi untuk meningkatkan keuntungan masyarakat lokal baik secara ekonomi, sosial, budaya dan menjaga kelestarian lingkungan. Kemitraan dalam lingkungan masyarakat yang merupakan sesuatu hal yang tidak asing untuk diterapkan, karena bangsa ini sudah mengenal kemitraan sejak berabad-abad lamanya meskipun dalam skala yang sederhana, seperti gotong royong, sambat sinambat, partisipasi, mitra cai, mitra masyarakat desa hutan, mitra lingkungan dan sebagainya. Dalam manajemen modern, baik dalam pengembangan sumberdaya manusia maupun pengembangan kelembagaan/ usaha, kemitraan merupakan salah satu strategi yang biasa ditempuh untuk mendukung keberhasilan implementasi manajamen modern (Kamil, 2006: 1). Kemitraan tidak sekadar diterjemahkan sebagai sebuah kerjasama, akan tetapi kemitraan memiliki bentuk, memiliki nilai strategis dalam mewujudkan keberhasilan suatu lembaga dalam menerapkan manajemen modern termasuk dalam pengembangan ekowisata.

Hal ini menarik untuk dikaji karena kawasan ekowisata selain merupakan sumber pendapatan masyarakat juga berfungsi untuk konservasi keanekaraganam hayati dan kelestarian budaya masyarakat lokal. Dengan demikian dipandang perlu diteliti 


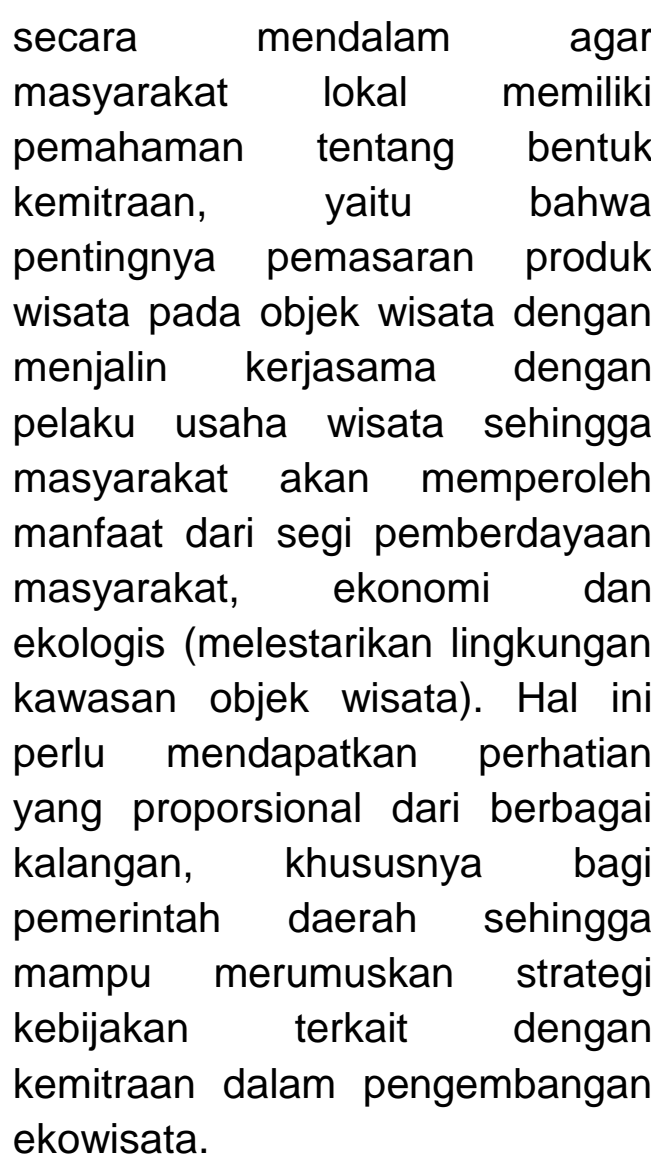

\section{HASIL DAN PEMBAHASAN}

1. Pihak yang Berperan dalam Pengembangan Ekowisata Tanah Lot Kabupaten Tabanan

Daya Tarik Wisata Tanah Lot merupakan salah satu obyek wisata yang ada di Kabupaten Tabanan Provinsi Bali. Perkembangannya cukup pesat, dapat dilihat dari penataan ruang kawasan, pembangunan dan pemeliharaan infrastruktur dan peningkatan kunjungan wisatawan tiap tahunnya. Adapun pihakpihak yang berperan dalam pengelolaan Daya Tarik Wisata Tanah Lot sebagai berikut.

\begin{abstract}
METODE
Penelitian ini dilakukan di Daya Tari Wisata Tanah Lot, Kabupaten Tabanan. Rancangan penelitian yang digunakan dalam penelitian ini adalah survai). Survai adalah metode pengumpulan informasi dari responden yang difasilitasi dengan daftar isian yang terstruktur (Effendi dan Singarimbun, 1989). Metode survei yang dipilih untuk menggali informasi yang bersifat kualitatif, serta didukung dengan metode observasi secara langsung di lapangan, dan wawancara mendalam (indepht interview). Analisis data dilakukan dengan teknik analisis kualitatif.
\end{abstract}

\subsection{Pemerintah Kabupaten} Tabanan

Dalam mengelola obyek wisata Tanah Lot, Desa Adat Beraban menjadi bagian dari instansi pemerintah, terutama dalam menangani bidang kepariwisataan ODTW Tanah Lot. Sesuai dengan peraturan Bupati Tabanan No. 40 tahun 2011 tentang Struktur Organisasi Badan Pengelola Daya Tarik Wisata Tanah Lot, yang menjadi ketua umum adalah Bupati Kabupaten Tabanan. 


\subsection{Desa Dinas Beraban}

Terdapat dua sistem pemerintahan desa yang ada di Bali yaitu desa dinas yang bersifat yuridis formal dan desa adat yang bersifat informal. Peranan pemerintah Desa Dinas Beraban merupakan pemerintahan terkecil yang secara yuridis formal mewakili warga Desa Beraban dalam berhubungan dengan instansi dari luar desa, baik pemerintah yang secara struktural berada diatasnya seperti pemerintah kecamatan, pemerintah kabupaten maupun provinsi dan pusat. Selain itu juga dari instansi lain seperti swasta. Dalam hal ini setiap instansi yang ingin menyampaikan program tentang kepariwisataan harus melalui Desa Dinas Beraban. Selanjutnya desa dinas akan berkoordinasikannya dengan desa adat.

\subsection{Desa Adat Beraban}

Desa adat adalah desa mengurusi bidang adat dan agama. Dengan adanya pengembangan kawasan ekowisata Tanah Lot. Bidang kegiatan menjadi bertambanh luas, selain menangani bidang adat dan agama, juga menangai kegiatan pariwisata di obyek wisata Tanah Lot. Dengan demikian Desa Adat Beraban mengadakan penataan terhadap organisasi desa adat sehingga memungkinkan untuk bertindak efektif.

\subsection{Pelaku Usaha Wisata}

Pelaku usaha wisata merupakan pihak yang memiliki peran yang tidak dapat diremehkan. Pedagang cendera mata, pelayanan jasa, restauran, hotel, dan pedagang makanan dan minuman termasuk kedalam potensi wisata. Wisatawan berkunjung ke obyek wisata tidak hanya untuk melihat sesuatu (something to see) untuk dinikmati seperti atraksi wisata dan melakukan berbagai kegiatan wisata (something to do) saja, tetapi juga menikmati apa yang dapat dibeli di obyek wisata (something to buy). Berbelanja merupakan salah satu kegiatan wisata, misalnya membeli sebuah kenang-kenangan atau cendera mata di obyek wisata akan dapat meningkatkan daya tarik wisatawan untuk berkunjung.

\subsection{Polisi Pariwisata}

Untuk memberikan rasa aman bagi wisatawan dan juga pengelolanya, maka di tempat wisata perlu didirikan beberapa fasilitas termasuk pos polisi pariwisata. Pembenahan pariwisata dimulai dari pengamanan aset-aset wisata 
sehingga dapat memberi rasa aman saat berwisata dan diharapkan akan merangsang para wisatawan untuk berkunjung.

\subsection{Dinas Perhubungan}

Dinas perhubungan (DISHUB) pada obyek wisata merupakan pihak yang memiliki tugas pokok diantaranya yaitu penyediaan parkir, penyediaan rambu-rambu, dan memperlancar arus transportasi di suatu obyek wisata. Khusus untuk obyek wisata Tanah Lot, karena sudah dikelola oleh adat maka tugas Dishub lebih sedikit yakni sebatas rambu dan fasilitas tapi secara khusus membantu kelancaran lalu lintas dan parkir, sedangkan pemungutan parkir sudah dilakukan oleh adat. Dengan demikian pihak Dishub hanya melakukan pengawasan dan membantu pelayanan. Kendala yang ditemui hampir tidak ada, karena sudah saling membantu dan mendukung baik dengan polisi, manajer dan desa adat

\section{Bentuk Kemitraan dalam Pengembangan Ekowisata Tanah Lot}

Dalam rangka merespon berbagai perubahan yang terjadi akibat berbagai kekurangan yang dimiliki masing-masing organisasi/lembaga, maka harus agresif mencari solusi manajemen yang lebih baik terutama untuk meningkatkan kinerja dan mempertahankan keuntungan kompetitif dengan menerapkan konsep-konsep manajemen modern. Kemitraan menjadi lebih dominan dalam sebuah organisasi modern sekalipun, dalam dunia global, komunikasi tanpa sekat, daya saing tingkat tinggi sulit sekali bagi sebuah organisasi untuk tidak melakukan kemitraan dengan pihak lainnya. Kemitraan memiliki tujuan untuk mencapai hasil yang lebih baik, dengan saling memberikan manfaat antara pihak yang bermitra atau dengan kata lain kemitraan hendaknya dapat memberikan keuntungan pada pihak-pihak yang bermitra dan bukan sebaliknya ada suatu pihak yang dirugikan atau merugikan.

Kemitraan dapat terjalin jika memenuhi persyaratan sesuai dengan konsep kemitraan seperti saling menguntungkan yang dilakukan dua pihak atau lebih untuk mencapai tujuan bersama pada posisi yang setara ataupun dalam posisi hubungan principalagent. Selain itu juga mengandung penjelasan mengenai aspek yang dimitrakan oleh pihak-pihak tersebut, sehingga melatarbelakangi terjadinya hubungan kemitraan.

Terjadinya kemitraan yang kuat dan saling menguntungkan dan memperbesar manfaat 
memerlukan komitmen antara satu dengan yang lainnya. Kemitraan dapat dilakukan oleh pihak-pihak baik perorangan, badan hukum, maupun kelompokkelompok (organisasi masyarakat). Kemitraan didasari atas hubungan antar pelaku yang bertumpu pada ikatan usaha yang saling menunjang dan saling menguntungkan berdasarkan atas kesetaraan dan kebersamaan. Setiap pelaku usaha memiliki potensi/ kemampuan dan keistimewaan sendiri, walaupun berbeda ukuran, jenis, sifat dan tempat usahanya. Setiap pelaku usaha juga memiliki kelebihan dan kekurangannya. Dengan demikian akan timbul kebutuhan kerjasama dan kemitraan, sehingga kelebihan akan dapat dilipatgandakan dengan memaksimalkan manfaat yang mungkin diperoleh. Sedangkan kekurangan dapat diusahakan untuk dikurangi, atau bahkan dihilangkan sama sekali dengan kerjasama yang saling menutupinya. Berdasarkan konsep tersebut, dalam pengembangan ekowisata Tanah Lot, terdapat dua dasar kemitraan yaitu sebagai berikut.

\subsection{Kemitraan berdasarkan status kepemilikan lahan}

Kepemilikan lahan di daerah penelitian ada tiga macam yaitu sebagai berikut. a. Lahan Milik Pemerintah Daerah

Kawasan wisata Tanah Lot berada di daerah administrasi Desa Beraban, namun dalam kepemilikan lahan tidak berarti sepenuhnya milik warga adat Desa Beraban. Pemerintah Kabupaten Tabanan memiliki sebagian lahan di kawasan wisata ini yaitu tepatnya pada lahan parkir di bagian utara pintu masuk kawasan wisata Tanah Lot. Hal ini akan berpengaruh pada hak pemanfaatan lahan parkir, baik dalam pemungutan karcis parkir ataupun membuka tempat usaha bagi pelaku usaha wisata. Tempat usaha para pedagang yang ada di lahan parkir dibuat blok-blok kios/ toko yang disebut pelataran. 6 (enam) pelataran yang tertata rapi. Pelataran khusus digunakan untuk menjual makan dan minuman dengan jumlah 46 pedagang yang berasal dari satu Kecamatan Kediri.

Pada awalnya lahan parkir hanya digunakan sebagai tempat parkir saja. Motivasi untuk memanfaatkan lahan parkir dengan membuat blok-blok kios/ toko bagi pedagang muncul dari pihak manajemen. Pihak manajemen melihat adanya pedagang acung/asongan yang menggangu kenyamanan wisatawan. Untuk menanggulangi hal tersebut maka disediakan tempat berdagang dengan 
memanfaatkan sebagian lahan parkir. Hal ini telah disetujui baik oleh pihak desa adat dan pemerintah daerah. Kesepakatan yang dibuat antara pihak manajemen yaitu menyewa/kontrak kios/ toko ke pemerintah daerah dan membayar retribusi harian ke pihak manajemen, akan tetapi pembangunan kios/ toko sepenuhnya diserahkan kepada pedagang. Pajak sewa tanah dihitung Rp.1500/m²/ hari dengan rata-rata luas kios/ toko $6 \mathrm{~m}^{2}$ yang masuk ke pemerintah daerah.

\section{b. Lahan Milik Desa Adat}

Desa adat memiliki Iahan yang berlokasi dibagian tengah kawasan wisata Tanah Lot tepatnya desebelah selatan lahan parkir sampai ke Pura Tanah Lot. Pada lahan ini dibangun kios/toko oleh pihak pengelola. Toko/ kios dibangun untuk tempat menjual cendera mata atau barang-barang kerajinan untuk souvenir. Selain itu juga untuk toko-toko modern seperti minimarket, restoran dan spa. Pelaku usaha wisata di lahan desa adat bersifat hak guna bangunan dengan membeli kios/ toko saja sedangkan lahan tetap milik desa adat. Dengan kata lain, hak untuk kepelikan kios/ toko merupakan milik pribadi dan dapat menyewakan atau menjual lagi ke pihak lain tetapi untuk kepemilikan lahan tetap milik dari desa adat.
Sistem pembayaran retribusi dari kios/ toko sebesar $2500 / \mathrm{m}^{2} /$ hari yang masuk ke badan pengelola. Luas rata-rata kios/ toko 12 $\mathrm{m}^{2}$ /blok kios/ toko. Pedagang bisa memiliki lebih dari satu blok tergantung jenis usahanya. Misalnya toko cendera mata akan berbeda dengan restaurant. Jumlah pelaku usaha wisata yang menempati lahan milik desa adat yaitu sebanyak 215 pelaku usaha wisata (pedagang dan pelayanan jasa).

c. Lahan milik pribadi/ warga
masyarakat Lahan di kawasan wisata Tanah Lot selain milik dari pemerintah daerah dan milik desa adat, sebagian warga desa juga memiliki lahan di kawasan obyek wisata Tanah Lot. Kepemilikan lahan oleh warga/ milik pribadi berada di pinggir jalan utama atau tepatnya di sebelah timur lahan parkir dan lahan milik desa adat. Hal ini akan berpengaruh pada kerjasama dengan pihak pengelola termasuk Desa Adat Beraban, yaitu dalam hal pembangunan kios/ tempat usaha. Pelaku usaha wisata bebas untuk mengembangkan usahanya yaitu dapat memperluas kiosnya. Hal ini berbeda dengan kios yang dibangun oleh pihak pengelola. Pembayaran retribusi tetap dikeluarkan berdasarkan ketentuan yang dibuat yaitu $\mathrm{Rp}$. 
2000/m²/hari. Jumlah dari pelaku usaha wisata yang menempati lahan milik pribadi yaitu sebanyak 137 pelaku usaha wisata.

Berdasarkan uraian tentang kemitraan berdasarkan status kepemilikan lahan terdapat makna bahwa proses kemitraan sudah berjalan di ODTW Tanah Lot. Hal ini ditunjukkan dari terdapatnya tiga status kepemilikan lahan pada satu kawasan obyek wisata Tanah Lot, diantaranya lahan milik Pemda Kabupaten Tabanan, lahan milik Desa Adat Beraban, dan lahan milik warga perorangan (pribadi). Terdapatnya tiga status kepemilikan lahan di kawasan ODTW Tanah Lot tidak menimbulkan konflik sosial, karena sudah terjadinya kemitraan diantara pihak yang memiliki lahan dan pihak yang membuka usaha di kawasan wisata Tanah Lot. Realisasi kemitraan dilakukan atas kesamaan tujuan dan saling membutuhkan untuk meningkatkan kapasitas dan kapabilitas pada bidang usaha kepariwisataan atau lebih khususnya dalam pengembangan ekowisata Tanah Lot.

\section{PENUTUP}

\section{Simpulan}

Berdasarkan hasil penelitian yang telah dibahas, simpulan yang yang dapat ditarik yaitu sebagai berikut.
1. Pihak yang terlibat dalam pengembangan ekowisata Tanah Lot adalah pemerintah daerah, pemerintah desa dinas, desa adat, pelaku usaha wisata.

2. Bentuk kemitraan masyarakat untuk pengembangan ekowisata Tanah Lot berdasarkan status kepemilikan lahan. Terdapat 3 status kepemilikan lahan yaitu lahan pribadi digunakan oleh masyarakat untuk wirausaha, lahan milik desa pakraman yang dibangun kios untuk disewakan dan lahan milik pemerintah daerah yang digunakan untuk lahan parkir.

\section{Rekomendasi}

1. Perlunya membuat sebuah kebijakan berupa sistem untuk mengatur pemerataan pendapatan bagi pelaku usaha wisata khususnya bagi para pedagang cendera mata (souvenir) dalam penerimaan wisatawan terutama wisatawan mancanegara yang berkunjung untuk berbelanja.

2. Perlu kajian lebih lanjut tentang kemitraan dalam pengembangan ekowisata tidak hanya pada pihak pengelola dengan pelaku usaha wisata, tetapi juga 
mengkaji kemitraan antar pelaku usaha wisata

\section{DAFTAR PUSTAKA}

Baiquni, M. 2010. Pariwisata Berkelanjutan dalam Pusaran Krisis Global. Denpasar: Udayana University Press.

Efendi, Sofian dan Singarimbun, Masri. $1987 . \quad$ Metode Penelitian Survai. Yogyakarta: LP3ES

Fandeli, Chafid dan Muklison. 2000. Pengusahaan Ekowisata.Yogyakarta: Fakultas Kehutanan UGM. Kamil, Mustofa. 2006. Strategi Kemitraan Dalam Membangun PNF Melalui
Pemberdayaan Masyarakat (Model, Keunggulan dan Kelemahan).

http://file.upi.edu/Direktori/S PS/PRODI.PENDIDIKAN_L UAR_SEKOLAH/19611109 1987031-

MUSTOFA_KAMIL/Bhaan_ kuliah/KEMITR 1.PDF.

Diakses tanggal 23 April 2015

Pendit. 2002. IImu Pariwisata Sebuah Pengantar Perdana. Jakarta : Pradnya Paramitha.

Western, David. 1995. Ekoturisme: Petunjuk Untuk Perencanaan \& Pengelolaan. Jakarta: The Ecotourism Society North Benington, Vermont. 